\title{
PASS-THROUGH OF EXCHANGE RATES AND IMPORT PRICES TO DOMESTIC INFLATION IN SOME INDUSTRIALIZED ECONOMIES
}

\author{
Jonathan McCarthy \\ Federal Reserve Bank of New York
}

\section{INTRODUCTION}

In most industrialized economies, inflation rates in the 1990s and 2000s were low compared to those of the 1970s and 1980s. Further underscoring these differences, inflation remained low even in countries-in particular, the United States- that experienced lengthy economic expansions. In fact, the inflation rate in the US continued to decline in the 1990s even as the unemployment rate fell below levels generally associated with rising inflation during the previous two decades.

Because of low inflation and because the relationship between inflation and economic activity in many countries during the past decade was contrary to the standard paradigm, economists have searched for "special factors" to explain this phenomenon. ${ }^{1}$ Among the more-cited special factors have been import prices and exchange rates: many analysts have pointed to a general decline of import prices in industrialized economies, partly induced by the 1997-98 Asian crisis, to explain declining inflation during the late 1990s. More narrowly, commentators have attributed a significant portion of the decline in inflation in the US and UK during the late 1990s to the disinflationary impact of exchange rate appreciation and import price deflation. ${ }^{2}$ For the US, some analysts also have suggested that the greater openness of the economy has increased foreign competitive pressures on domestic firms, thus restraining domestic inflation to a greater extent than in previous episodes of dollar appreciation.

Clearly then, the extent to which exchange rates and import prices influence domestic inflation is of major concern for monetary policy. ${ }^{3}$ If the lower inflation of the 1990s can be attributed largely to such special factors, then a reversal of such factors could herald higher future inflation. For example, many analysts were concerned that as emerging market economies recovered from the 1997-98 crisis, the resulting higher import prices would lead to greater inflationary pressures in the industrialized economies. In fact, the European Central Bank cited the inflationary effects of a weak euro as a factor behind its tightening of monetary policy in 2000 and the disinflationary effects of a strong euro as a factor behind the loosening in $2003 .^{4}$

Beyond the policy implications, economists long have been interested in the influence of exchange rate and import price fluctuations on domestic inflation. Accordingly, this subject has spawned many studies through the years. Most have concentrated

Jonathan McCarthy: Macroeconomic and Monetary Studies Function, Federal Reserve Bank of New York, 33 Liberty St., New York, NY 10045. E-mail: jonathan.mccarthy@ny.frb.org. 
on the pass-through of a country's exchange rate fluctuations to its import prices, a literature that has been surveyed comprehensively by Goldberg and Knetter [1997]. ${ }^{5}$ There also have been a number of studies on the pass-through to domestic producer and consumer prices; some examples include Woo [1984], Feinberg [1986; 1989], and Parsley and Popper [1998].

Although much recent work concentrated on pass-through at the firm or industry level, several recent studies have examined macroeconomic pass-through in the US and other countries. In one case of the latter, Dellmo [1996] finds that the effect of import prices on the CPI in Swedish data is weak, a surprising result given that Sweden is a small open economy. For the large, relatively closed US economy, a number of papers—for example, Gordon [1998], Stock [1998], Koenig [1998], and Rich and Rissmiller [2000] —find that import prices explain a substantial portion of the forecast error and improves forecasts during the 1990s.

Two recent papers in particular pertain to this paper. Campa and Goldberg [2005] estimate exchange rate pass-through to import prices for OECD countries, a broader set than used in this paper. For countries common to the two papers, their results are consistent with those in this paper. However, the model in this paper allows for analysis further along the pricing chain (to producer and consumer prices) than can be done in their single equation model. Choudhri, Faruqee, and Hakura [2005] use similar techniques as in this paper to examine pass-through to import, producer, and consumer prices in the non-US G7 countries, a narrower set of countries compared to this paper. Moreover, their model has a less extensive real and monetary sector than the model in this paper (although it is more extensive in other directions). Where there are common results, most of their results are consistent with those in this paper.

Returning to this paper, I use a VAR model that permits one to track pass-through from exchange rate fluctuations to each stage of the distribution chain in a simple integrated framework. The model has a similar structure to that of Clark [1999], who studies responses of prices at different production stages to monetary policy shocks. However, his model does not explicitly include exchange rates and import prices. ${ }^{6}$ In addition, I estimate the model for several industrialized economies and examine whether the factors affecting pass-through that have been identified in the industrylevel studies also explain cross-country differences.

To preview the results, the impulse response functions indicate that exchange rate shocks have modest effects on domestic inflation in most of the countries in the sample, while import price shocks appear to have a larger effect. Pass-through appears to be larger in countries with a higher import share of domestic demand as well as in countries with more persistent exchange rates and import prices. Variance decompositions suggest that the role of exchange rate and import price shocks in explaining consumer price fluctuations is relatively modest.

The remainder of this paper proceeds as follows. The next section discusses influences on pass-through that have been identified in previous studies and that may explain cross-country differences. The next two sections describe the model and its empirical implementation, as well as the data. The following section discusses the results and then there is a concluding section. 


\section{INFLUENCES ON PASS-THROUGH}

Even within a simple supply-demand model where the law of one price holds, there can be cross-country variation in the pass-through of exchange rate fluctuations to domestic prices. In a large country, the inflationary effect of a currency depreciation on domestic prices is counteracted by a decline in the world price (because of lower world demand), reducing the measured pass-through. For a small country, a currency depreciation would have no effect on world prices, and thus pass-through would be complete in the simple model. Therefore, even within the confines of this model, passthrough should be greater in smaller economies.

Still, pass-through appears to vary more-across countries and time as well as across industries within a country - than can be expected in the simple model. Consequently, many studies have examined firms' adjustment of markups in response to exchange rate fluctuations. A theoretical basis for these studies is Dornbusch [1987], who applied industrial organization models to explain pass-through in terms of market concentration, import penetration, and the substitutability of imported and domestic products. Utilizing these principles, Feinberg [1986; 1989] found exchange rate pass-through to domestic producer prices in the US and Germany to be greater in industries that were less concentrated and faced greater import penetration. More generally, Goldberg and Knetter [1997] concluded that the pass-through to import prices is smaller in more segmented industries where firms are able to engage in third degree price discrimination.

What do these results imply for cross-country differences in pass-through? If a country's import share can be assumed to be a good proxy for the import penetration faced by firms, then a country with a larger import share should have greater pass-through of exchange rate and import price fluctuations to domestic prices. ${ }^{7}$ In addition, both because of a direct effect as well as through a greater pass-through, exchange rates and import prices should be more important in explaining domestic price fluctuations as the import share increases.

Recent studies investigating the "pricing-to-market" hypothesis of Krugman [1987] and Marston [1990] suggest additional influences on pass-through. Pricing-to-market behavior occurs when exporters base their foreign currency export prices on competitive conditions in their foreign markets. As such, exporters allow profit margins, rather than foreign currency prices, to fluctuate in response to exchange rate fluctuations. Knetter [1993] finds that a firm's industry matters more than its nationality for pricing-to-market behavior. This suggests that cross-country differences in pass-through may reflect differences in industrial composition. Also, if firms pay less attention to pricing strategies in smaller markets, pricing-to-market may occur less and passthrough should be larger in smaller economies (as measured by GDP).

Using the pricing-to-market principles, Mann [1986] discusses some macroeconomic variables that may affect pass-through. One is exchange rate volatility. Greater exchange rate volatility may make importers more wary of changing prices and more willing to adjust profit margins, thus reducing pass-through. Wei and Parsley [1995] and Engel and Rogers [1998] have provided some empirical evidence confirming this 
hypothesis at the sectoral and product level. ${ }^{8}$ Thus pass-through should be less in countries where the exchange rate has been more volatile.

In a similar vein, if firms expect exchange rate or import price shocks to be persistent, they are more likely to change prices rather than adjust profit margins in response to changes in the exchange rate or import prices, which would increase pass-through. ${ }^{9}$ Taylor [2000] developed a model that formalizes this intuition and provided some evidence from the US supporting his model. Thus pass-through should be greater in countries where fluctuations in exchange rates and import prices have displayed greater persistence.

Another macroeconomic variable discussed by Mann [1986] is aggregate demand uncertainty. Aggregate demand shifts in conjunction with exchange rate fluctuations will alter the profit margins of importers in an imperfectly competitive environment, thus reducing measured pass-through. If this hypothesis is true, pass-through should be less in countries where aggregate demand (which will be proxied by the output gap) is more volatile.

\section{MODEL AND METHODOLOGY}

To examine the pass-through of exchange rate and import price fluctuations to domestic producer and consumer inflation across countries, I use a model of pricing along a distribution chain. ${ }^{10}$ Inflation at each stage-import, producer, and consumer-in period $t$ is assumed to be comprised of several components. The first component is the expected inflation at that stage based on the available information at the end of period $t$-1. The second and third are the effects of period $t$ domestic "supply" and "demand" shocks on inflation at that stage. The fourth component is the effect of exchange rate shocks on inflation at a particular stage. Next are the effects of shocks at the previous stages of the chain. Finally, there is that stage's shock.

The shocks at each stage are that portion of a stage's inflation that cannot be explained using information from period $t$ - 1 plus contemporaneous information about domestic supply and demand variables, exchange rates, and inflation at previous stages of the distribution cycle. These shocks can be thought of as changes in the pricing power and markups of firms at these stages. Two other features of the model are worthy of note. First, the model allows import inflation shocks to affect domestic consumer inflation both directly and indirectly through their effects on producer inflation. Second, there is no contemporaneous feedback in the model: for example, consumer inflation shocks affect inflation at the import and producer stages only through their effect on expected inflation in future periods.

Under these assumptions, the inflation rates of country $i$ in period $t$ at each of the three stages-import, producer (PPI), and consumer (CPI)—can be written as: ${ }^{11}$

$$
\begin{gathered}
\pi_{i t}^{m}=E_{t-1}\left(\pi_{i t}^{m}\right)+\alpha_{1 i} \varepsilon_{i t}^{s}+\alpha_{2 i} \varepsilon_{i t}^{d}+\alpha_{3 i} \varepsilon_{i t}^{e}+\varepsilon_{i t}^{m} \\
\pi_{i t}^{w}=E_{t-1}\left(\pi_{i t}^{w}\right)+\beta_{1 i} \varepsilon_{i t}^{s}+\beta_{2 i} \varepsilon_{i t}^{d}+\beta_{3 i} \varepsilon_{i t}^{e}+\beta_{4 i} \varepsilon_{i t}^{m}+\varepsilon_{i t}^{w}
\end{gathered}
$$




$$
\pi_{i t}^{c}=E_{t-1}\left(\pi_{i t}^{c}\right)+\gamma_{1 i} \varepsilon_{i t}^{s}+\gamma_{2 i} \varepsilon_{i t}^{d}+\gamma_{3 i} \varepsilon_{i t}^{e}+\gamma_{4 i} \varepsilon_{i t}^{m}+\gamma_{5 i} \varepsilon_{i t}^{w}+\varepsilon_{i t}^{c}
$$

where $\pi_{i t}^{m}, \pi_{i t}^{w}$, and $\pi_{i t}^{c}$ are import price, PPI, and CPI inflation respectively; $\varepsilon_{i t}^{s}, \varepsilon_{i t}^{d}$, and $\varepsilon_{i t}^{e}$ are the supply, demand, and exchange rate shocks respectively; $\varepsilon_{i t}^{m}, \varepsilon_{i t}^{w}$, and $\varepsilon_{i t}^{c}$ are the import price, PPI, and CPI inflation shocks; and $E_{t-1}(\bullet)$ is the expectation of a variable based on the information set at the end of period $t$-1. The shocks are assumed to be serially uncorrelated as well as uncorrelated with one another within a period.

To complete the model, we specify the supply, demand, and exchange rate shocks, as well as the interaction between monetary policy and other variables in the model. To identify aggregate demand and supply shocks and exchange rate shocks, we make the following assumptions. (1) Supply shocks $\left(\varepsilon_{i t}^{s}\right)$ are identified from the dynamics of oil price inflation denominated in the local currency $\left(\pi_{i t}^{\text {oil }}\right){ }^{12}(2)$ Demand shocks $\left(\varepsilon_{i t}^{d}\right)$ are identified from the dynamics of the output gap $\left(\tilde{y}_{i t}\right)$ in the country after taking into account the contemporaneous effect of the supply shock. (3) Exchange rate shocks $\left(\varepsilon_{i t}^{e}\right)$ are identified from the dynamics of exchange rate appreciation $\left(\Delta e_{i t}\right)$ after taking into account the contemporaneous effects of the supply and demand shocks. ${ }^{13}$ The equations of this portion of the model then are the following.

$$
\begin{gathered}
\pi_{i t}^{o i l}=E_{t-1}\left(\pi_{i t}^{o i l}\right)+\varepsilon_{i t}^{s} \\
\tilde{y}_{i t}=E_{t-1}\left(\tilde{y}_{i t}\right)+a_{1 i} \varepsilon_{i t}^{s}+\varepsilon_{i t}^{d} \\
\Delta e_{i t}=E_{t-1}\left(\Delta e_{i t}\right)+b_{1 i} \varepsilon_{i t}^{s}+b_{2 i} \varepsilon_{i t}^{d}+\varepsilon_{i t}^{e}
\end{gathered}
$$

Because monetary policy may react to exchange rate fluctuations and because policy also eventually affects exchange rates and domestic inflation, the last portion of the model consists of a central bank reaction function and a money demand equation in the spirit of Christiano, Eichenbaum, and Evans [1996]. ${ }^{14}$ The reaction function relates short-term interest rates $\left(r_{i t}\right)$ to the previously cited variables in the model as central banks use the short-term rate as their monetary policy instrument. The money demand function relates money growth $\left(\Delta m_{i t}\right)$ to the other variables in the model.

$$
\begin{gathered}
r_{i t}=E_{t-1}\left(r_{i t}\right)+c_{1 i} \varepsilon_{i t}^{s}+c_{2 i} \varepsilon_{i t}^{d}+c_{3 i} \varepsilon_{i t}^{e}+c_{4 i} \varepsilon_{i t}^{m}+c_{5 i} \varepsilon_{i t}^{w}+c_{6 i} \varepsilon_{i t}^{c}+\varepsilon_{i t}^{M P} \\
\Delta m_{i t}=E_{t-1}\left(\Delta m_{i t}\right)+d_{1 i} \varepsilon_{i t}^{s}+d_{2 i} \varepsilon_{i t}^{d}+d_{3 i} \varepsilon_{i t}^{e}+ \\
d_{4 i} \varepsilon_{i t}^{m}+d_{5 i} \varepsilon_{i t}^{w}+d_{6 i} \varepsilon_{i t}^{c}+d_{7 i} \varepsilon_{i t}^{M P}+\varepsilon_{i t}^{M D}
\end{gathered}
$$

Finally, I assume that the conditional expectations $\left(E_{t-1}(\bullet)\right)$ in equations $(1)-(8)$ can be replaced by linear projections on lags of the eight variables in the system. Mak- 
ing this replacement, the model can be expressed and estimated as a VAR using a Cholesky decomposition to identify the shocks. The impulse responses of PPI and CPI inflation to the orthogonalized shocks of exchange rate appreciation and import price inflation then provide estimates of the effect of these variables on domestic inflation. In addition, variance decompositions of PPI and CPI inflation enable one to determine the importance of these "external" variables for domestic inflation.

In using a Cholesky decomposition to identify the shocks in the model, one issue that arises concerns the identification of aggregate demand and supply shocks. Although the model assumes that oil price inflation is affected contemporaneously only by aggregate supply shocks, it truly may be affected contemporaneously by both aggregate supply and demand shocks. If so, each of the shocks in the first two equations of the VAR would be a combination of aggregate supply and demand shocks. ${ }^{15}$ However, even in that case, this should have little effect on the measurement of exchange rate and import prices shocks and their effect on domestic inflation, which is the principal concern of this study.

\section{DATA}

Data from nine developed countries - the United States, Japan, Germany, France, the United Kingdom, Belgium, the Netherlands, Sweden, and Switzerland-are used in this study. ${ }^{16}$ The data are quarterly and limited to the floating exchange rate period, and mostly come from national sources. ${ }^{17}$ To account for lags in the construction of some variables and in the model specifications, the estimation period runs from 1976:1 through 1998:4 for most countries. ${ }^{18}$

As far as the variables used in this study, the exchange rate is the quarterly average of the nominal effective exchange rate. Depending upon availability, import prices are either a general import price index or an index of import unit values. The PPI is the most general producer or wholesale price index that excludes imports: imports were excluded because the broadest available PPI in some countries-in particular, the United States-do not include imports. ${ }^{19}$ The CPI is the overall consumer price index to provide the broadest measure of inflation at the consumer level. Because of the numerous methodological changes in the US CPI in recent years, I use the current methods CPI research series. ${ }^{20}$ The output gap is created by taking the deviations of the log of real GDP from a quadratic trend. ${ }^{21}$ The interest rate variable is an overnight interest rate, comparable to the US Federal funds rate; as such rates have been shown to be good indicators of monetary policy actions. ${ }^{22}$ For the money variable, I use a broad monetary aggregate, primarily because such aggregates are generally available on a consistent basis. An appendix (available upon request) provides country-specific details about the variables.

Annualized percentage changes of the price indices and average output gaps and interest rates over five-year periods as well as the last three years of the sample are presented in Table 1. This summary provides some insight into the questions and problems of measuring the pass-through of exchange rates and import prices to domestic prices. In particular, the table shows that many declines in domestic inflation have been associated with exchange rate appreciation and import price disinflation/deflation (and vice versa), and suggests that these external factors may have played a role in the disinflation of the 1990s. 
TABLE 1

Summary statistics for various periods Annualized percentage changes over the periods

\begin{tabular}{|c|c|c|c|c|c|c|c|c|}
\hline Country & $\begin{array}{c}\text { Oil } \\
\text { prices }\end{array}$ & $\begin{array}{c}\text { Output } \\
\text { gap }^{\mathrm{a}}\end{array}$ & $\begin{array}{c}\text { Exch. } \\
\text { rate }\end{array}$ & $\begin{array}{c}\text { Imp. } \\
\text { prices }\end{array}$ & PPI & CPI & $\begin{array}{c}\text { Int. } \\
\text { rate }^{\mathrm{a}}\end{array}$ & Money \\
\hline \multicolumn{9}{|c|}{ United States } \\
\hline $1976-80$ & 26.3 & 1.5 & -1.4 & 13.1 & 9.3 & 8.3 & 8.6 & 9.3 \\
\hline $1981-85$ & -15.4 & -1.8 & 3.4 & -2.1 & 2.1 & 4.4 & 11.2 & 9.2 \\
\hline $1986-90$ & 2.4 & 2.0 & -5.8 & 3.2 & 3.2 & 3.9 & 7.7 & 5.6 \\
\hline $1991-95$ & -1.3 & -1.5 & 0.0 & -0.1 & 1.3 & 2.5 & 4.5 & 2.1 \\
\hline $1996-98$ & -13.0 & 0.4 & 4.7 & -3.9 & 0.3 & 1.9 & 5.4 & 6.3 \\
\hline \multicolumn{9}{|l|}{ Japan } \\
\hline $1976-80$ & 16.9 & 0.3 & 8.1 & 7.2 & 5.2 & 6.1 & 6.9 & 10.8 \\
\hline $1981-85$ & -16.9 & -2.2 & 5.5 & -4.4 & -0.6 & 2.3 & 6.8 & 8.5 \\
\hline $1986-90$ & -4.3 & 0.5 & 2.9 & -4.7 & -0.3 & 1.6 & 5.0 & 9.8 \\
\hline $1991-95$ & -5.9 & 1.6 & 5.4 & -4.2 & -1.2 & 0.9 & 3.7 & 1.9 \\
\hline $1996-98$ & -9.0 & -0.8 & -1.0 & -0.8 & -0.9 & 1.1 & 0.4 & 3.7 \\
\hline \multicolumn{9}{|l|}{ Germany } \\
\hline $1976-80$ & 21.2 & 1.9 & 3.7 & 6.9 & 4.1 & 4.2 & 5.3 & 8.3 \\
\hline $1981-85$ & -13.4 & -1.9 & 3.1 & 0.7 & 2.5 & 3.2 & 7.2 & 6.1 \\
\hline $1986-90$ & -6.0 & -1.1 & 2.5 & -1.8 & 1.2 & 1.7 & 5.4 & 8.7 \\
\hline $1991-95$ & -2.1 & 2.6 & 1.7 & -0.5 & 1.1 & 3.4 & 7.1 & 6.4 \\
\hline $1996-98$ & -9.1 & -1.5 & -1.4 & -0.7 & 0.0 & 1.3 & 3.3 & 5.9 \\
\hline \multicolumn{9}{|l|}{ France } \\
\hline $1976-80$ & 28.1 & 0.9 & -2.5 & 13.7 & 10.9 & 10.9 & 9.3 & 12.9 \\
\hline $1981-85$ & -8.4 & -1.0 & -2.9 & 5.9 & 7.8 & 8.4 & 12.9 & 10.2 \\
\hline $1986-90$ & -4.0 & 0.5 & 0.0 & 0.4 & 1.7 & 3.2 & 8.5 & 8.4 \\
\hline $1991-95$ & -2.0 & -0.1 & 1.7 & -0.1 & 0.3 & 2.2 & 8.1 & 2.0 \\
\hline $1996-98$ & -9.7 & -0.1 & -0.6 & 0.0 & -1.1 & 0.9 & 3.4 & 0.4 \\
\hline \multicolumn{9}{|c|}{ United Kingdom } \\
\hline $1976-80$ & 22.7 & 0.9 & 1.9 & 9.7 & 13.6 & 13.4 & 11.3 & 14.6 \\
\hline $1981-85$ & -7.0 & -3.4 & -5.1 & 6.6 & 6.5 & 6.3 & 11.5 & 14.8 \\
\hline $1986-90$ & -3.2 & 3.7 & -0.4 & 1.5 & 4.4 & 6.3 & 11.6 & 15.6 \\
\hline $1991-95$ & 3.1 & -1.3 & -4.2 & 4.7 & 3.5 & 2.9 & 7.8 & 5.6 \\
\hline $1996-98$ & -15.9 & -0.3 & 7.3 & -5.3 & 0.7 & 3.1 & 6.6 & 7.6 \\
\hline \multicolumn{9}{|l|}{ Belgium } \\
\hline $1976-80$ & 22.6 & $3.4^{\mathrm{b}}$ & 1.6 & $14.3^{\mathrm{b}}$ & 4.4 & 8.0 & 9.0 & 7.6 \\
\hline $1981-85$ & -9.2 & -1.2 & -2.1 & 6.0 & 4.9 & 6.3 & 11.1 & 7.1 \\
\hline $1986-90$ & -5.8 & 0.3 & 1.7 & -1.0 & -0.1 & 2.2 & 7.9 & 9.6 \\
\hline $1991-95$ & -2.2 & 0.6 & 1.4 & 0.4 & 0.7 & 2.3 & 7.4 & 4.3 \\
\hline $1996-98$ & -8.9 & -0.7 & -1.4 & 0.5 & -0.7 & 1.3 & 3.4 & 6.0 \\
\hline \multicolumn{9}{|c|}{ Netherlands } \\
\hline $1976-80$ & 22.3 & $1.2^{\mathrm{c}}$ & 1.6 & 8.2 & 4.0 & 5.7 & 7.3 & $10.0^{c}$ \\
\hline $1981-85$ & -12.8 & -1.8 & 2.1 & -0.8 & 2.5 & 3.4 & 7.3 & 7.3 \\
\hline $1986-90$ & -5.9 & 0.6 & 1.9 & -2.4 & -1.1 & 1.0 & 6.1 & 7.6 \\
\hline $1991-95$ & -2.4 & 0.7 & 1.5 & -0.3 & 0.4 & 2.7 & 6.9 & 4.7 \\
\hline $1996-98$ & -8.6 & -0.7 & -1.6 & -1.9 & 0.1 & 2.0 & 3.1 & 8.2 \\
\hline \multicolumn{9}{|l|}{ Sweden } \\
\hline $1976-80$ & 27.3 & -0.4 & -2.0 & 12.8 & 10.8 & 10.9 & 9.3 & 10.9 \\
\hline $1981-85$ & -6.7 & -1.6 & -5.0 & 6.7 & 7.9 & 7.9 & 13.0 & 6.2 \\
\hline $1986-90$ & -2.8 & 2.9 & -0.8 & 2.3 & 4.3 & 7.0 & 10.9 & 8.3 \\
\hline $1991-95$ & 2.2 & -1.6 & -2.9 & 3.7 & 2.6 & 2.8 & 12.1 & 4.1 \\
\hline $1996-98$ & -7.7 & 0.2 & -2.6 & 0.2 & 0.0 & 0.2 & 4.8 & 3.5 \\
\hline \multicolumn{9}{|c|}{ Switzerland } \\
\hline $1976-80$ & 18.8 & -2.6 & 4.8 & 2.8 & 1.7 & 2.8 & 1.4 & 7.6 \\
\hline $1981-85$ & -14.7 & -0.6 & 3.7 & 0.3 & 2.3 & 3.7 & 3.9 & 4.9 \\
\hline $1986-90$ & -5.7 & 1.7 & 1.8 & -0.7 & 1.4 & 3.1 & 4.5 & 6.3 \\
\hline $1991-95$ & -3.2 & 0.6 & 2.3 & -0.9 & 0.0 & 2.5 & 5.4 & 4.0 \\
\hline $1996-98$ & -8.7 & -1.4 & -1.5 & -1.5 & -1.3 & 0.3 & 1.5 & 2.4 \\
\hline
\end{tabular}

Notes: a. Average over the period. $\quad$ b. 1980 only. c. $1977-80$. 
Nonetheless, there also have been cases where countries have experienced sizable swings in exchange rates and import prices with little effect on domestic prices. For example, the exchange rate depreciated over 1996-98 in Japan, Germany, and France, but the depreciations were associated with only a moderate increase in inflation (Japan) or disinflation (Germany, France). Other factors obviously have been important in the disinflation experienced by these countries, the most prominent probably being the decline in oil prices. Therefore, econometric analysis using the model presented in the previous section is required to determine the role of exchange rates and import prices in domestic inflation.

\section{RESULTS}

As discussed in the model section, we estimate a VAR consisting of eight variables: oil price inflation, the output gap, exchange rate change, import price inflation, PPI inflation, CPI inflation, short-term interest rate, and money growth. ${ }^{23}$ The reduced form residuals from the VAR are orthogonalized using a Cholesky decomposition to identify the structural shocks, where the variables are in the order given above.

For each country, the number of lags in the VAR is set at four (a constant is the only other variable included in the regressions), and the model is estimated over the period 1976:1-1998:4 (92 quarters), a period before the introduction of the euro in a number of the European countries in the sample. Two sets of statistics are used to assess the pass-through from exchange rate fluctuations and import price inflation to domestic inflation. First, impulse responses to the exchange rate and import price shocks are estimated over a two-year (8-quarter) horizon. ${ }^{24}$ These are standardized to correspond to the response to a one percent shock in the exchange rate or import price index to allow a comparison of the sensitivity to these factors across countries. Second, variance decompositions are used to measure the percentage of the forecast variance in domestic price indices that can be attributed to these factors, providing an assessment of their importance for domestic inflation.

\section{Responses to exchange rate shocks}

Figures 1-3 display the responses of the import price index, the PPI, and the CPI to an exchange rate shock in each of the countries of the sample. In this model, the exchange rate shock is estimated given past values of all variables plus current values of oil prices and the output gap. The solid line in each graph is the estimated response while the dashed lines denote a two standard error confidence band around the estimate. ${ }^{25}$

The initial impact of an exchange rate appreciation on import prices is negative as expected and remains so for at least a year in all of the countries (Figure 1). By the end of two years, the response is imprecisely estimated in many countries, and there are cases where it is positive. For the US, the pass-through is similar to previous estimates as well as common perceptions concerning exchange rate pass-through. ${ }^{26}$ The pass-through is particularly large in Belgium and the Netherlands, with the eventual change in import prices exceeding one percent. On the other hand, the pass-through is surprisingly small in Sweden and Switzerland. 
The response of the PPI appears to be fairly weak in most of the countries (Figure 2). Statistically, the estimates are not significantly different from zero, and for Japan the response has the wrong sign. The exceptions to this pattern are Belgium and the Netherlands. The estimates for the US are somewhat weaker than those in Feinberg [1989], but the estimates for Germany are similar to those in Feinberg [1986].

The response of the CPI to the exchange rate shock is smaller than that of the PPI, and is statistically insignificant in most cases (Figure 3). Furthermore, a number of responses have the wrong (positive) sign, particularly in Japan and France. Again, the exceptions to this pattern are Belgium and the Netherlands. The pass-through in the US is similar to the results of Woo [1984] for the pass-through to the consumption price deflator and of Parsley and Popper [1998] for the pass-through to the CPI.

To judge the magnitude of these responses, I compare the estimated responses to the 1976-97 average of the ratio of imports to private final consumption expenditures. ${ }^{27}$ Ignoring any effects on competing domestic goods, if exchange rate fluctuations were passed through completely down the distribution chain, the effect on the CPI would roughly be the imports-expenditure ratio since the CPI is weighted by expenditures. Therefore, this ratio can be considered to be a lower bound of a large pass-through to the CPI. In Figure 4, (the negative of) this ratio is pictured as the horizontal dashed line while the estimated response is the solid line. As can be seen in the figure, the responses are not nearly as large as this standard, suggesting that the pass-through to CPI is modest in these countries.

Although the pass-through estimates are small and imprecise, there are noticeable differences across countries. To assess explanations for these differences, I calculate the Spearman rank correlation between the impulse responses at various horizons and some factors expected to influence pass-through. From the discussion in the second section, the factors are: (1) mean import share (imports as a percentage of domestic demand) over 1985-98;28 (2) 1975 GDP in US dollars using purchasing power parities from the OECD (as a measure of market size); ${ }^{29}$ (3) exchange rate persistence measured by the impulse response at the 8-quarter horizon of the exchange rate to its own standardized shock; $; 3$ (4) exchange rate volatility measured by the variance of the residuals from the exchange rate equation; (5) aggregate demand volatility measured by the variance of the residuals from the output gap equation; and (6) as a measure of industrial composition, the average manufacturing sector share of GDP by value added over 1980-94.

The rank correlations are mostly in accord with the hypotheses discussed in the second section (Table 2). Higher import shares, more persistent and less volatile exchange rates, and less volatile GDP are correlated with a greater import price response, although the relationship is statistically significant only for exchange rate persistence and volatility (panel a). However, manufacturing share and 1975 GDP display no strong correlation with the import price response.

The results for the PPI response are similar to those for import prices, although the correlations for import share and exchange rate volatility are stronger while the correlations for exchange rate persistence are weaker (panel b). In addition, both GDP and manufacturing share are negatively correlated with this response. The latter correlation is consistent with pricing-to-market in the manufacturing sector. Finally, most of the correlations between these factors and the response of the CPI are weaker 


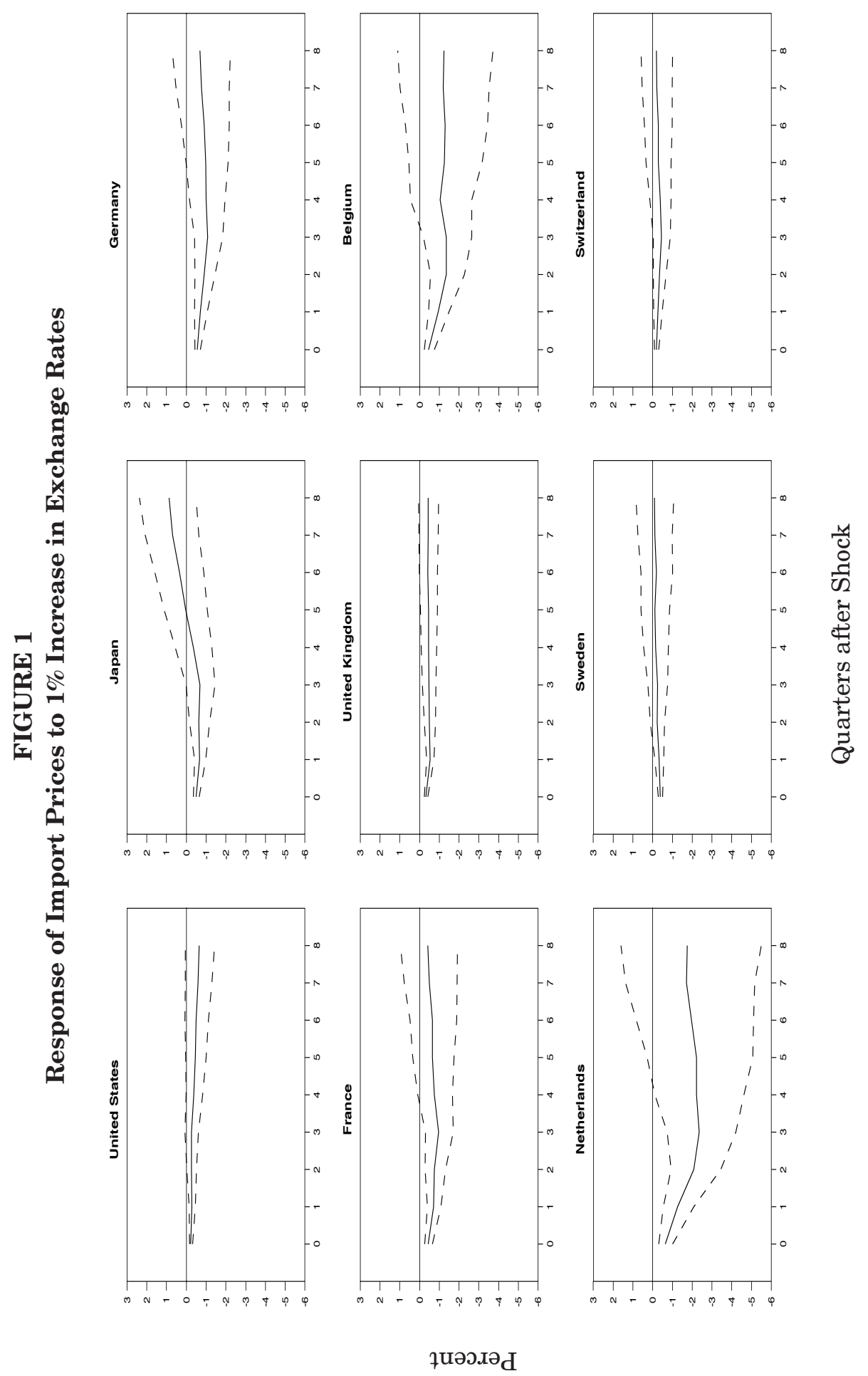




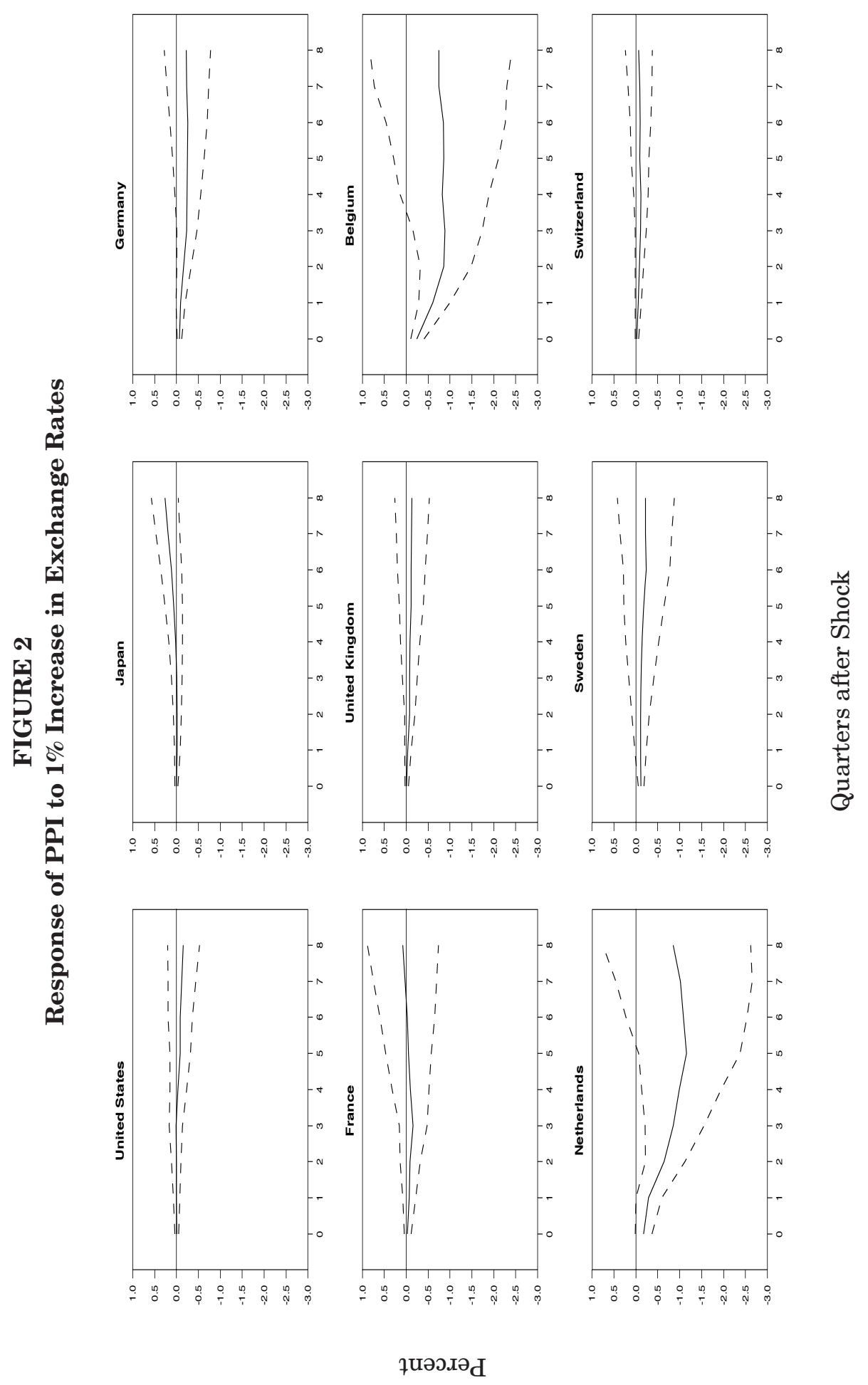




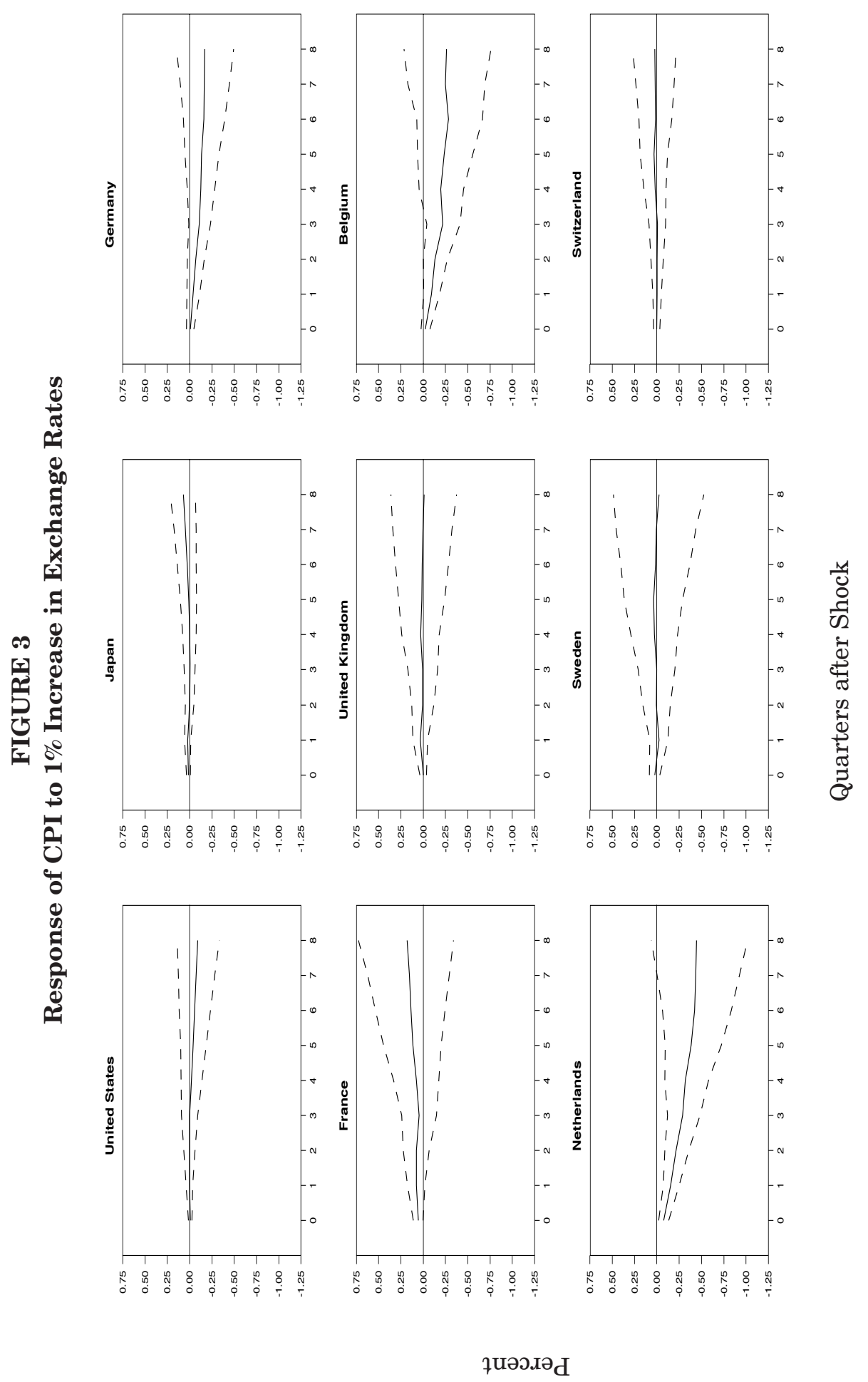


than those for the PPI (panel c). The exceptions are exchange rate persistence, which is strongly positively correlated with the response at all horizons, and manufacturing share, which remains negatively correlated with the response. Import share and exchange rate volatility have the expected correlations and these are statistically significant at some horizons.

\section{TABLE 2}

\section{Rank correlation between impulse responses to exchange} rates and factors influencing pass-through

\section{(a) Impulse response of import prices}

\begin{tabular}{lcccc} 
(a) Impulse response of import prices & \multicolumn{2}{c}{ Response horizon } \\
Factor & $\mathbf{0}$ & $\mathbf{1}$ & $\mathbf{4}$ & $\mathbf{8}$ \\
\hline Import share & 0.067 & 0.333 & 0.450 & 0.433 \\
1975 GDP (US\$) & 0.217 & 0.083 & 0.033 & 0.033 \\
Ex. rate persistence & 0.400 & $0.583^{* *}$ & $0.867^{* * *}$ & $0.917^{* * *}$ \\
Ex. rate volatility & $-0.500^{*}$ & $-0.700^{* *}$ & $-0.750^{* *}$ & $-0.683^{* *}$ \\
GDP volatility & 0.033 & -0.217 & -0.300 & -0.150 \\
Avg. mfg. share $^{\mathrm{a}}$ & 0.214 & 0.071 & -0.119 & -0.405
\end{tabular}

(b) Impulse response of PPI

\begin{tabular}{|c|c|c|c|c|}
\hline Import share & $0.833 * * *$ & $0.817 * * *$ & $0.800 * * *$ & $0.567^{*}$ \\
\hline 1975 GDP (US\$) & $-0.583 * *$ & $-0.600 * *$ & $-0.567 *$ & -0.267 \\
\hline Ex. rate persistence & $0.517 *$ & 0.450 & $0.650 * *$ & $0.700 * *$ \\
\hline Ex. rate volatility & $-0.900 * * *$ & $-0.867 * * *$ & $-0.883 * * *$ & $-0.700 * *$ \\
\hline GDP volatility & 0.167 & 0.183 & 0.317 & 0.283 \\
\hline Avg. mfg. share ${ }^{a}$ & -0.357 & -0.238 & -0.310 & $-0.500 *$ \\
\hline \multicolumn{5}{|c|}{ (c) Impulse response of CPI } \\
\hline Import share & 0.333 & $0.583 * *$ & 0.267 & 0.433 \\
\hline 1975 GDP (US\$) & 0.017 & -0.383 & 0.067 & -0.117 \\
\hline Ex. rate persistence & $0.867 * * *$ & $0.667 * *$ & $0.800 * * *$ & $0.750 * *$ \\
\hline Ex. rate volatility & -0.433 & $-0.633^{* *}$ & -0.450 & $-0.567 *$ \\
\hline GDP volatility & 0.050 & 0.417 & 0.083 & 0.233 \\
\hline Avg. mfg. share ${ }^{a}$ & -0.357 & -0.429 & -0.357 & $-0.500 *$ \\
\hline \multicolumn{5}{|c|}{ * $\quad$ Significant at the 10 percent level (critical value $=0.467$ ) } \\
\hline ** Significant at th & level (crit & $e=0.583)$ & & \\
\hline \\
\hline \multicolumn{5}{|c|}{$\begin{array}{l}\text { *** Significant at the } 1 \text { percent level (critical value }=0.767 \text { ) } \\
\text { a. Because of data limitations, Switzerland is excluded from the rankings for this category. The critical } \\
\text { values thus are } 0.500,0.619 \text {, and } 0.810 \text { at the } 10,5 \text {, and } 1 \text { percent significance levels. }\end{array}$} \\
\hline
\end{tabular}

To summarize, the impulse responses indicate considerable (although not complete) pass-through of exchange rate fluctuations to import prices in most of these countries. In contrast, pass-through to the PPI and CPI is economically modest for the most part, results consistent with pricing-to-market behavior. Higher import shares, more persistent and less volatile exchange rates, and less volatile GDP are associated with larger pass-through.

\section{Responses to import price shocks}

Figures 5 and 6 display the responses of the PPI and the CPI to an import price shock. In the model, the import price shock is estimated given past values of all 


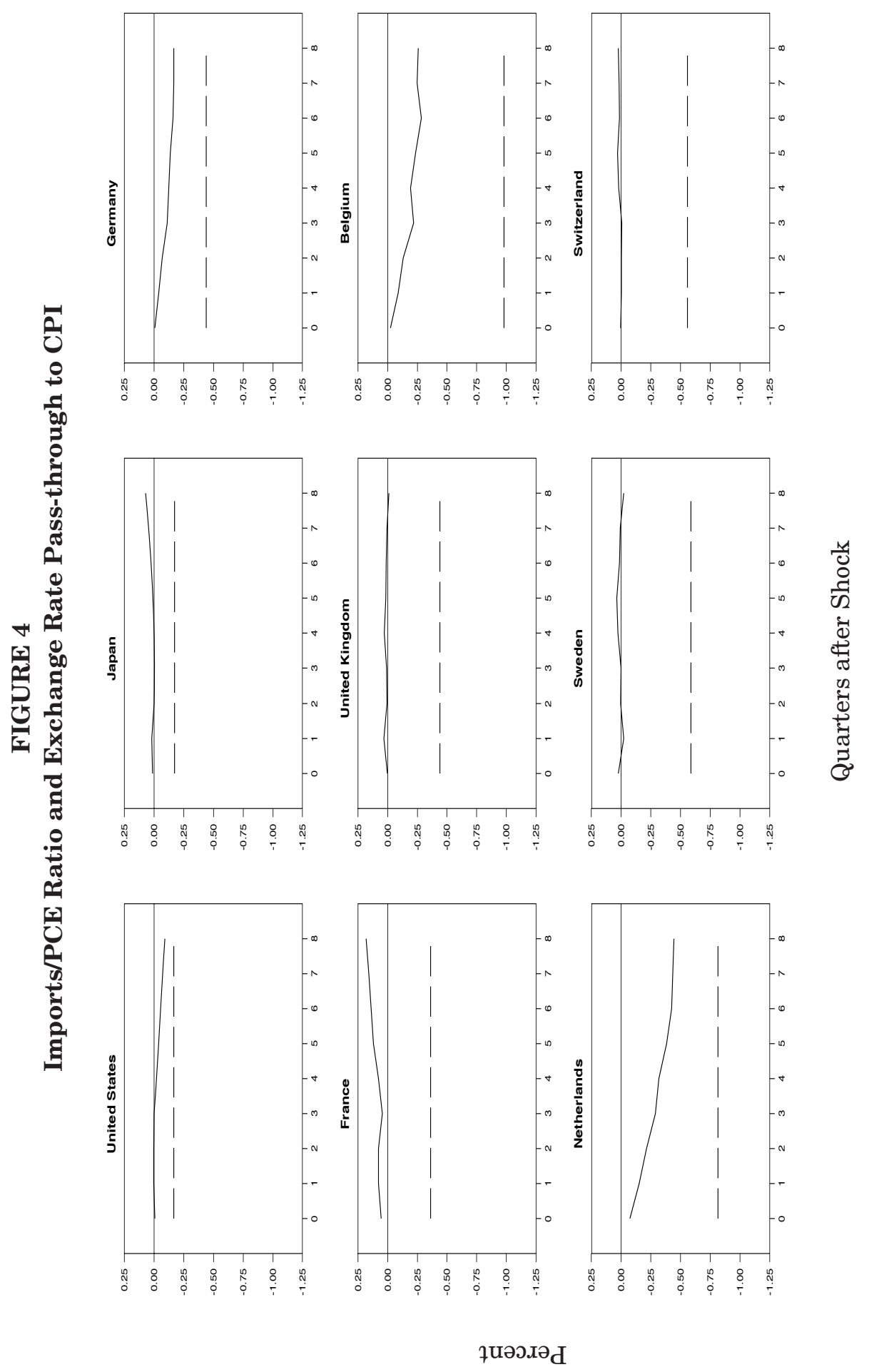


variables plus the current value of oil prices, the output gap, and the exchange rate. Therefore, these shocks are uncorrelated with exchange rate movements, but are likely to be related to movements in world commodity prices, changes in importers' profit margins, etc. These responses then should be informative about the pass-through from an import price decline like that induced by the 1997-98 Asian crisis.

The response of the PPI to an import price shock is positive as expected and usually statistically significant (Figure 5). The responses are particularly large in Belgium and Sweden, with the pass-through eventually exceeding 100 percent. In contrast, the pass-through is rather small in Japan.

The response of consumer prices to an import price shock is also positive and usually statistically significant, although smaller than the PPI response (Figure 6). In absolute terms, the pass-through is largest in Sweden, quite large in the US, and small in Japan. Comparing these responses to the import-private consumption expenditures ratio, they appear to be "large" after two years in most of these countries, with the exceptions being Japan, Belgium, and the Netherlands (Figure 7). Especially noteworthy is the response in the US, which is at its import-expenditures ratio on impact and rises well above this standard over the next two years.

\section{TABLE 3}

\section{Rank Correlation between Impulse Responses to Import Prices and Factors Influencing Pass-through}

(a) Impulse response of PPI

\begin{tabular}{lcccc}
\hline & \multicolumn{4}{c}{ Response horizon } \\
Factor & $\mathbf{0}$ & $\mathbf{1}$ & $\mathbf{4}$ & $\mathbf{8}$ \\
\hline Import share & 0.267 & 0.433 & 0.267 & 0.317 \\
1975 GDP (US\$) & -0.250 & -0.450 & -0.233 & -0.300 \\
Imp. price persistence & $0.833^{* * *}$ & $0.933^{* * *}$ & $0.850^{* * *}$ & $0.900^{* * *}$ \\
Ex. rate volatility & -0.333 & -0.350 & -0.167 & -0.200 \\
GDP volatility & 0.167 & 0.217 & 0.100 & 0.133 \\
Avg. mfg. share & -0.095 & -0.071 & -0.238 & -0.238
\end{tabular}

(b) Impulse response of CPI

\begin{tabular}{|c|c|c|c|c|}
\hline & \multicolumn{4}{|c|}{ Import share } \\
\hline 1975 GDP (US\$) & -0.033 & -0.017 & -0.183 & -0.283 \\
\hline Imp. price persistence & 0.250 & 0.233 & $0.483 *$ & $0.683^{* *}$ \\
\hline Ex. rate volatility & 0.300 & 0.450 & 0.250 & 0.067 \\
\hline GDP volatility & 0.350 & 0.333 & 0.450 & 0.167 \\
\hline Avg. mfg. share ${ }^{a}$ & -0.310 & 0.048 & -0.190 & -0.381 \\
\hline \multicolumn{5}{|c|}{ * Significant at the 10 percent level (critical value $=0.467)$} \\
\hline \multicolumn{5}{|c|}{$* * \quad$ Significant at the 5 percent level (critical value $=0.583)$} \\
\hline \multicolumn{5}{|c|}{$* * *$ Significant at the 1 percent level (critical value $=0.767)$} \\
\hline a. Because of data lir & & luded fron & & cy. The critical \\
\hline
\end{tabular}

I next examine the cross-country rank correlations between these responses and the six factors listed in the previous subsection (Table 3). For the PPI, a higher import share, a smaller economy, and a less volatile exchange rate are associated with a larger pass-through, although these relationships are statistically insignificant (panel a). In 


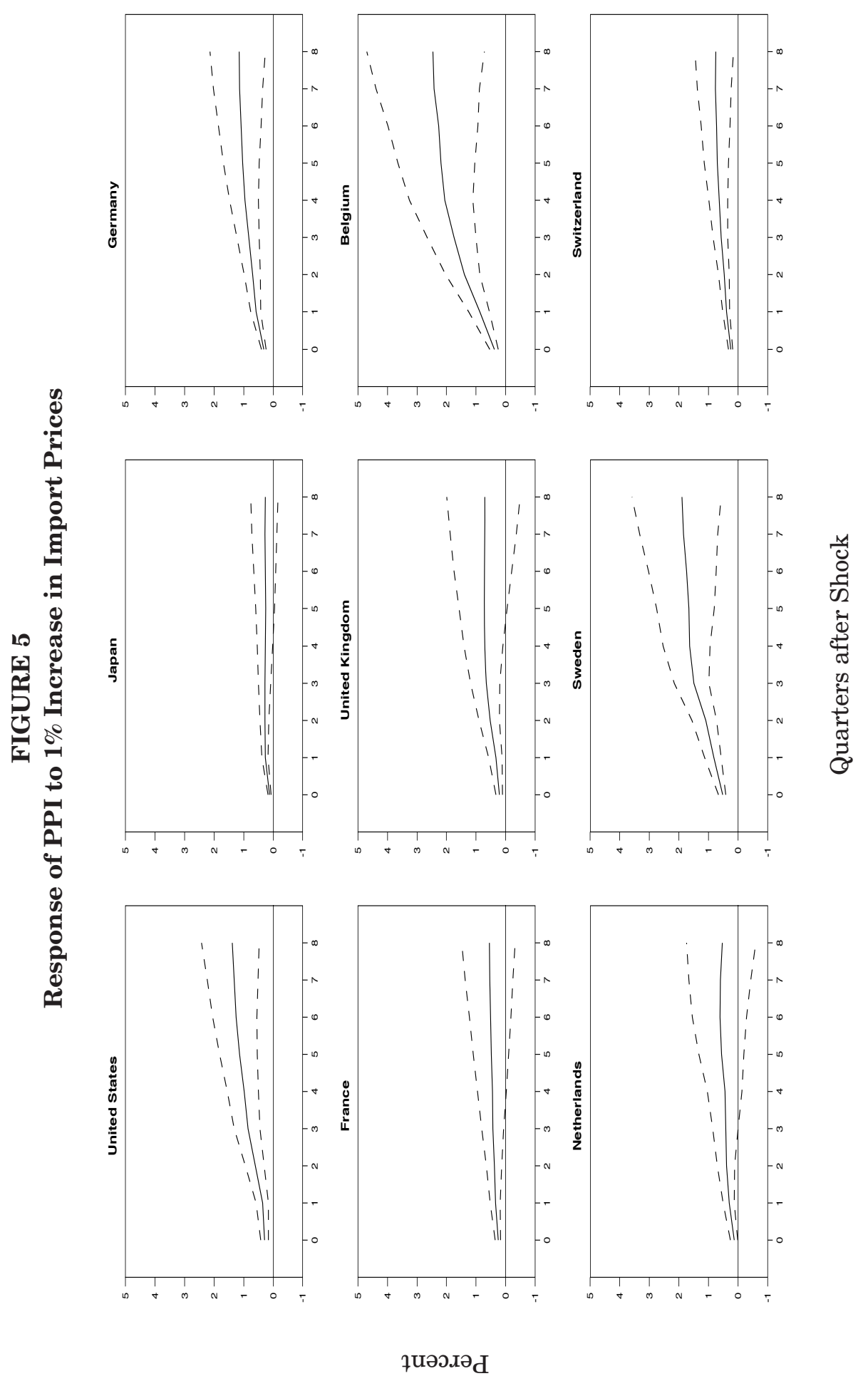




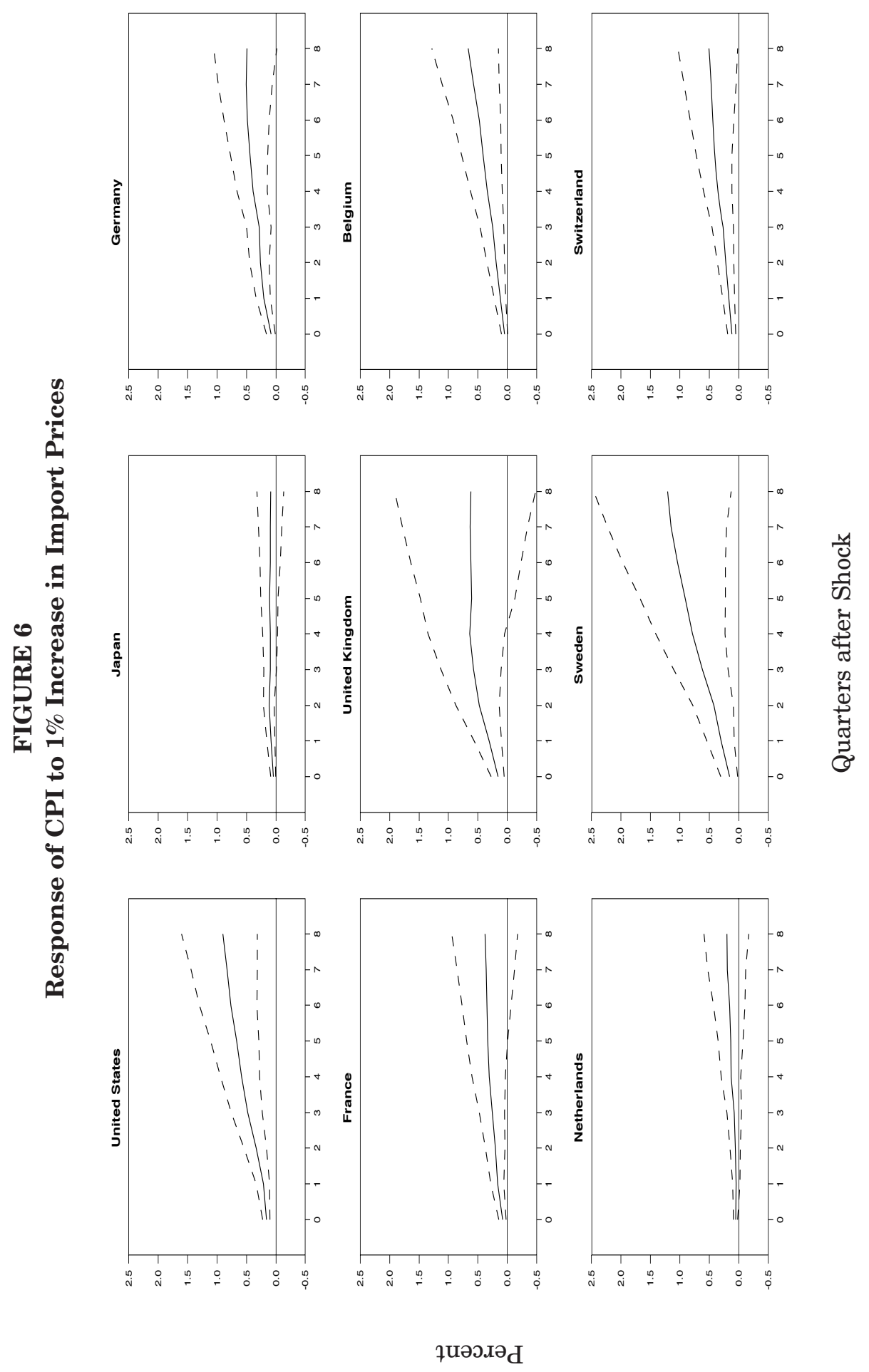




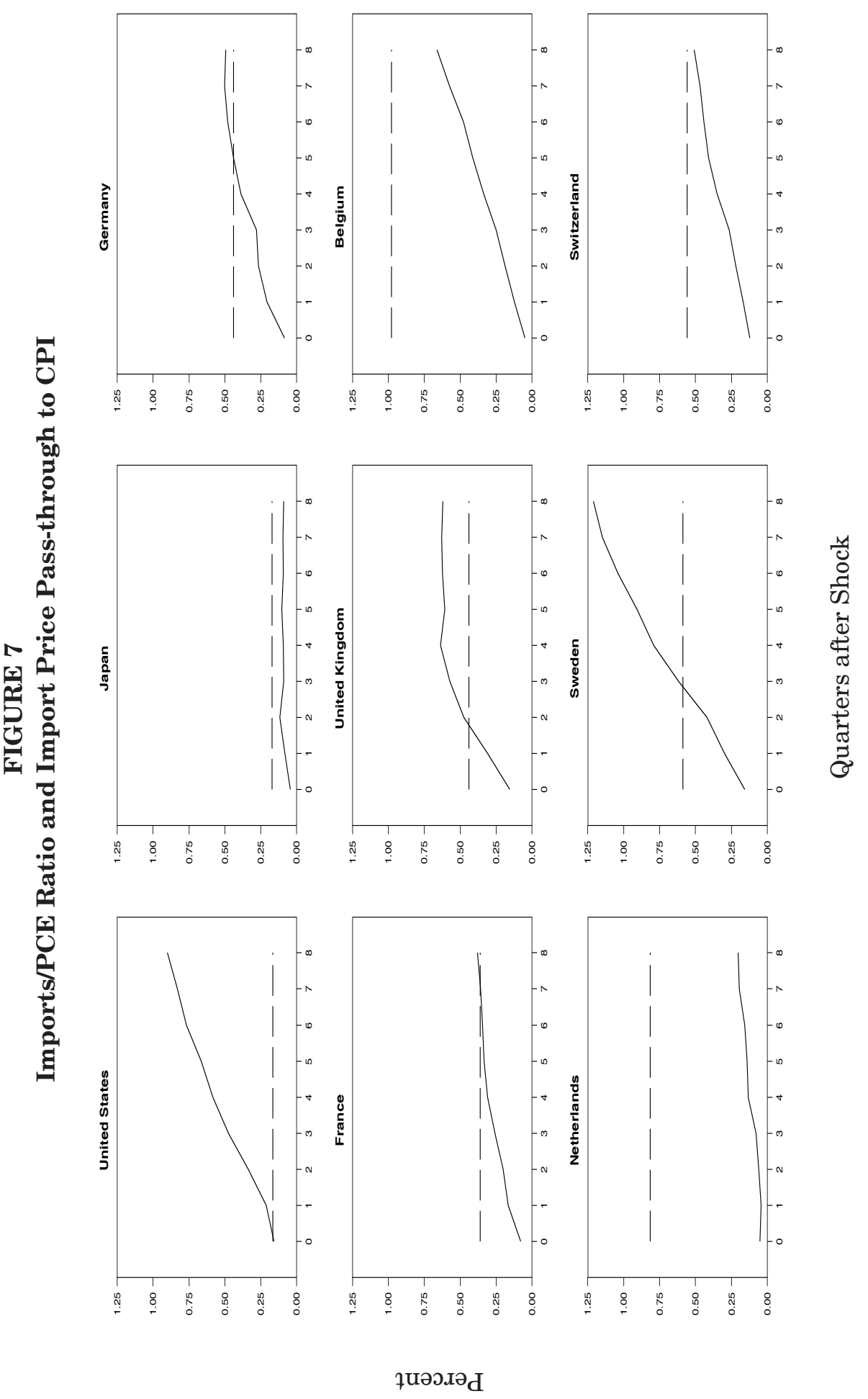


contrast, import price persistence is strongly correlated with a larger response at all horizons. Manufacturing share displays no strong relationship.

Turning to the CPI, the correlations between the responses and these factors are less clear cut than those for the other responses (panel b). Only the correlation between import price persistence and the CPI response has the expected sign and is statistically significant at longer horizons. The weak correlations suggest that pass-through of import prices to consumer prices vary across countries more idiosyncratically than do other pass-throughs, possibly reflecting country-specific market structures and industrial composition that are not captured by these variables.

\section{Variance decomposition}

Although the impulse responses indicate the extent of pass-through to domestic prices, they do not indicate how important these shocks have been in domestic price fluctuations. If the exchange rate and import price shocks in a country are small, then pass-through could be large but exchange rates and import prices would have little influence on domestic inflation. Therefore, to investigate the importance of these external factors, I examine the variance decompositions of the price variables.

For import prices, exchange rate shocks are especially important in explaining import price variance in the UK, where their share ranges from over 25 to 40 percent (Table 4) ${ }^{31}$ In the other countries, exchange rates explain from 5 to 30 percent (with most between 10 and 20 percent) of import price forecast variance initially. This percentage declines in all countries except the Netherlands as the forecast horizon increases so that it ranges from 2 to 12 percent at the two-year horizon (again, except for the UK).

The lower part of Table 4 displays the rank correlations between the percentage of import price variance attributed to exchange rate shocks and the factors listed in the responses to exchange rates subsection. Import share is negatively associated with this percentage, although the relationship is strong only at impact. Exchange rate persistence is negatively correlated with this percentage at shorter horizons, but positively correlated at longer horizons. Exchange rate volatility is positively associated with this percentage at impact, suggesting the larger exchange rate fluctuations counteract the smaller import price response to exchange rate shocks documented previously. However, there is little relationship at longer horizons. Manufacturing share is significantly positively correlated with this percentage, which may be surprising given that pricing-to-market is thought to be important in manufacturing.

For producer prices, the percentage of variance explained by exchange rates and import prices is quite large in many countries, which may be surprising since these PPIs exclude imported goods (Table 5). These factors explain one-third or more of variance of PPI (at least for some horizons) in five countries-Germany, France, Belgium, Sweden, and Switzerland. Although not negligible, their contribution in the other countries is more modest. The differences across countries are negatively related with economic size as expected, but are positively related with manufacturing share at short horizons, which is less expected. This percentage also is positively correlated with import price persistence. 
TABLE 4

Percentage of Import Price Forecast Variance Attributed to Exchange Rate Shocks

\begin{tabular}{lccrr}
\hline \multicolumn{4}{c}{ Forecast horizon } & $\mathbf{4}$ \\
Country & $\mathbf{0}$ & $\mathbf{1}$ & 8.3 & $\mathbf{8}$ \\
\hline United States & 20.4 & 14.9 & 7.3 & 6.1 \\
Japan & 21.3 & 15.0 & 17.8 & 13.1 \\
Germany & 29.5 & 21.1 & 15.4 & 9.4 \\
France & 17.0 & 19.0 & 30.7 & 25.6 \\
United Kingdom & 41.2 & 39.9 & 15.4 & 12.1 \\
Belgium & 12.5 & 18.7 & 15.3 & 12.4 \\
Netherlands & 5.8 & 9.1 & 4.9 & 2.2 \\
Sweden & 27.8 & 16.3 & 7.9 & 5.5 \\
Switzerland & 10.3 & 7.6 & & -0.150 \\
Spearman rank correlation & coefficient with: & & 0.133 & 0.417 \\
Import share & $-0.633^{* *}$ & -0.217 & 0.133 & $0.500^{*}$ \\
1975 GDP (US $\$$ ) & 0.367 & 0.233 & $0.533^{*}$ & -0.100 \\
Ex. rate persistence & $-0.567^{*}$ & -0.200 & -0.283 & -0.117 \\
Ex. rate volatility & $0.567^{*}$ & 0.033 & -0.183 & 0.024 \\
GDP volatility & 0.267 & -0.133 & 0.238 & \\
Avg. mfg. share & $0.524^{*}$ & $0.667^{* *}$ & & \\
\hline
\end{tabular}

* Significant at the 10 percent level (critical value $=0.467$ )

$* * \quad$ Significant at the 5 percent level (critical value $=0.583$ )

$* * *$ Significant at the 1 percent level (critical value $=0.767$ )

a. Because of data limitations, Switzerland is excluded from the rankings for this category. The critical values thus are $0.500,0.619$, and 0.810 at the 10,5 , and 1 percent significance levels.

TABLE 5

Percentage of PPI Forecast Variance Attributed to Exchange Rate and Import Price Shocks

\begin{tabular}{lcccc}
\hline & \multicolumn{2}{c}{ Forecast horizon } & $\mathbf{8}$ \\
Country & $\mathbf{0}$ & $\mathbf{1}$ & $\mathbf{4}$ & 25.4 \\
\hline United States & 13.3 & 11.0 & 21.5 & 14.9 \\
Japan & 18.3 & 26.9 & 14.5 & 38.5 \\
Germany & 44.2 & 39.4 & 39.1 & 15.3 \\
France & 34.8 & 30.5 & 19.4 & 11.5 \\
United Kingdom & 16.7 & 14.4 & 16.1 & 64.9 \\
Belgium & 23.9 & 39.5 & 61.0 & 17.7 \\
Netherlands & 7.7 & 13.0 & 17.3 & 44.2 \\
Sweden & 49.6 & 45.9 & 51.1 & 40.6 \\
Switzerland & 46.6 & 53.1 & 47.7 & $0.483^{*}$ \\
Spearman rank correlation & coefficient with: & & $-0.533^{*}$ \\
Import share & 0.150 & 0.367 & $0.600^{* *}$ & 0.233 \\
1975 GDP (US $\$$ ) & $-0.500^{*}$ & $-0.683^{* *}$ & $-0.617 * *$ & $0.933^{* * *}$ \\
Ex. rate persistence & -0.417 & -0.250 & 0.283 & -0.267 \\
Imp. price persistence & $0.467^{*}$ & $0.550^{*}$ & $0.983^{* * *}$ & 0.400 \\
Ex. rate volatility & -0.017 & -0.050 & -0.383 & -0.238 \\
GDP volatility & 0.450 & 0.433 & 0.367 & -0.310 \\
Avg. mfg. share & $0.524^{*}$ & 0.381 & & \\
\hline
\end{tabular}

* Significant at the 10 percent level (critical value=0.467)

** Significant at the 5 percent level (critical value $=0.583$ )

*** Significant at the 1 percent level (critical value $=0.767$ )

a. Because of data limitations, Switzerland is excluded from the rankings for this category. The critical values thus are $0.500,0.619$, and 0.810 at the 10,5 , and 1 percent significance levels. 
The influence of exchange rates and import prices on CPI variance is less than it is for PPI, even though imported goods are included in CPI (Table 6). In most of the countries, these factors explain less than 25 percent of the variance of the CPI, although this percentage tends to increase as the forecast horizon increases. At longer horizons this percentage tends to be higher for countries with a larger import share, greater exchange rate and import price persistence, lower exchange rate volatility, and a smaller manufacturing sector.

TABLE 6

Percentage of CPI Forecast Variance Attributed to Exchange Rate and Import Price Shocks

\begin{tabular}{lcccc}
\hline \multicolumn{5}{c}{ Forecast horizon } \\
Country & $\mathbf{0}$ & $\mathbf{1}$ & $\mathbf{4}$ & $\mathbf{8}$ \\
\hline United States & 19.1 & 13.2 & 19.9 & 23.4 \\
Japan & 5.7 & 10.2 & 9.0 & 6.8 \\
Germany & 5.8 & 13.0 & 21.3 & 19.6 \\
France & 12.3 & 17.5 & 17.5 & 15.8 \\
United Kingdom & 8.5 & 10.8 & 11.2 & 7.4 \\
Belgium & 3.7 & 11.4 & 28.4 & 39.1 \\
Netherlands & 15.9 & 20.2 & 23.3 & 20.6 \\
Sweden & 5.4 & 8.8 & 16.9 & 20.4 \\
Switzerland & 11.5 & 13.2 & 16.5 & 18.1 \\
Spearman rank correlation coefficient with: & & & \\
Import share & -0.167 & 0.233 & $0.583^{* *}$ & $0.517^{*}$ \\
1975 GDP (US\$) & 0.333 & 0.133 & -0.217 & -0.183 \\
Ex. rate persistence & 0.300 & $0.683^{* * *}$ & $0.817^{* * * *}$ & $0.650^{* *}$ \\
Imp. price persistence & -0.450 & -0.200 & $0.733^{* * *}$ & $0.733^{* * *}$ \\
Ex. rate volatility & -0.033 & $-0.533^{*}$ & $-0.767^{* * *}$ & $-0.600^{* *}$ \\
GDP volatility & -0.200 & -0.333 & 0.083 & -0.033 \\
Avg. mfg. share & -0.357 & -0.286 & -0.429 & $-0.667^{* *}$ \\
\hline
\end{tabular}

* Significant at the 10 percent level (critical value=0.467)

** Significant at the 5 percent level (critical value $=0.583$ )

*** Significant at the 1 percent level (critical value $=0.767$ )

a. Because of data limitations, Switzerland is excluded from the rankings for this category. The critical values thus are $0.500,0.619$, and 0.810 at the 10,5 , and 1 percent significance levels.

The variance decompositions thus indicate that external factors explain a modest proportion of the variance of domestic consumer prices over the post-Bretton Woods era. As expected, the influence of these factors is greater in more open economies and in countries where exchange rates and import prices display persistence.

\section{The role of pass-through in recent years}

To assess whether pass-through has had a larger effect in recent years on domestic inflation in these countries, we did two exercises. The first is an examination of a historical decomposition of the model for the period 1996:1-1998:4, concentrating on the CPI ${ }^{32}$ In this decomposition, a base projection is made using the data through 1995:4 and assuming no subsequent shocks. Then using the estimated shocks to each of the variables, the projection error is decomposed into the contributions from each shock. 
This decomposition presented in Table 7 allows us to investigate the sources of the low CPI inflation of the late 1990s. The first column displays the actual annualized percentage change of CPI over 1995:4-1998:4. The second column has the base projection, and the third has the projection error (projection - actual). The last four columns display the contributions of the shocks combined into four groups: demand and supply shocks (oil price and output gap), external factors (exchange rate and import price), domestic price shocks (PPI and CPI), and monetary shocks (interest rate and money). The contribution is defined as the difference between the base projection and the projection that includes the associated shocks. ${ }^{33}$

TABLE 7

Historical decomposition of CPI: 1995:4-1998:4

Annualized percentage changes

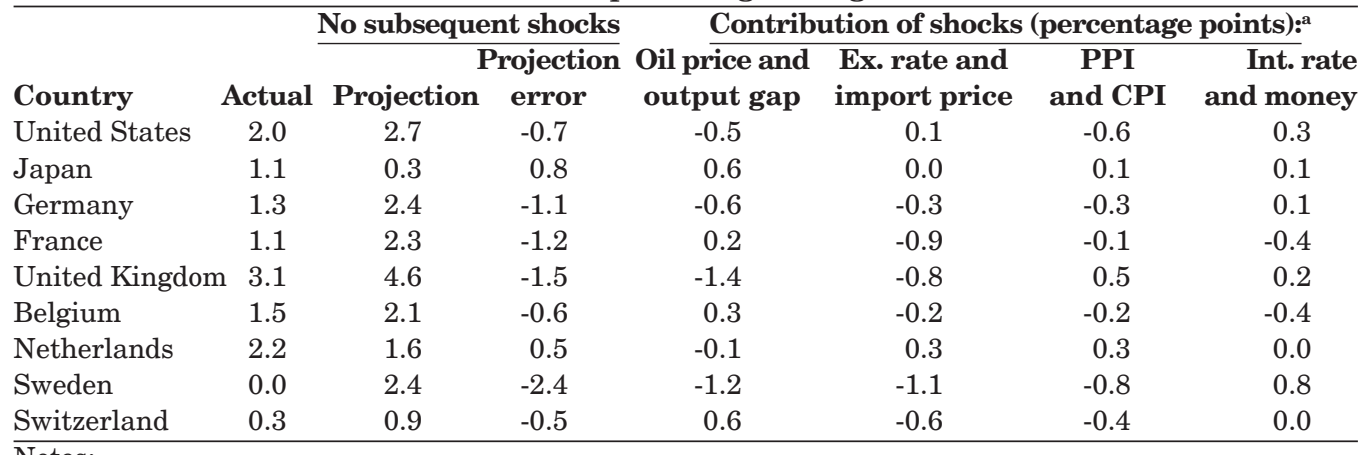

a. Because the model is estimated in log differences while CPI inflation in this table is expressed as an annualized precentage rate and because of rounding error, the contributions of the shocks do not add up exactly to the projection error.

According to the model, with the exclusion of Japan and the Netherlands, consumer price inflation was exceptionally low in these countries in the late $1990 \mathrm{~s}$, as actual CPI inflation was below the base projection. Shocks to the external factors were negative contributors in two-thirds of the countries; however, one major exception is the US. In that country, aggregate demand and supply shocks-in particular, the oil price decline-as well as domestic price shocks are identified as the disinflationary forces. Domestic price shocks also were disinflationary factors in the most of the other countries. Monetary shocks contributed little to the below-projection inflation except in France and Belgium, suggesting that these countries may have conducted a tighter monetary policy in anticipation of the introduction of the euro.

Therefore, external shocks have contributed to the late 1990s disinflation in many cases, suggesting that the import price decline stemming from the Asian crisis had a notable impact on inflation in those countries. However, despite the appreciation of the US dollar and the decline in import prices, these factors had little effect on the US disinflation once the oil price decline is taken into account. ${ }^{34}$ Domestic price shocks also were a disinflationary factor in most of these countries, suggesting that there may have been changes in pricing behavior that reduced inflation.

In the second exercise, we investigate whether pass-through to domestic inflation may have changed. When discussing the influence of exchange rates and import prices 
on domestic inflation, some analysts point to greater global integration as a reason for a greater pass-through of these factors. On the other hand, central banks have been more concerned with price stability during the last two decades. This would imply that monetary authorities may have counteracted the inflationary impact of external shocks, reducing measured pass-through over time. ${ }^{35}$

We use a simple strategy of estimating the model over a shorter period from 1983:1 to 1998:4. For brevity, we only summarize the results. ${ }^{36}$ They suggest that exchange rates and import prices have not assumed a bigger role in domestic consumer price inflation in recent years, and may even have had a smaller role. The conclusion that the pass-through is modest still appears to hold in this later period.

\section{CONCLUSION}

This paper has examined the pass-through of external factors-exchange rates and import prices-to domestic inflation for several industrialized economies. Using a VAR model that incorporates a distribution chain, I find that the pass-through to aggregate consumer prices, which is the principal concern for monetary policy, appears to be modest in most of these countries. Still, these factors did have a disinflationary effect during the late 1990s in many of these countries, with the prominent exception of the US.

This latter result for the US is probably the most surprising, as Gordon [1998], Stock [1998], and Koenig [1998] all find that external factors improved the forecast of US consumer price inflation in the mid- to late-1990s. I attribute these differences to differing methodologies. The previously cited papers used single equation methods where exchange rates and import prices are exogenous. Within such models, the decline in US inflation in the 1990s as the US dollar appreciated and import prices fell would indicate that these external factors contributed to the US disinflation of the period.

However, in the VAR model of this paper, the changes in the US exchange rate and import prices were largely explained by the behavior of the variables in the system, so the shocks to exchange rates and import prices contribute relatively little to the US disinflation. Instead, the unusual behavior (at least according to the model) occurs in oil prices and pricing behavior so that oil price, PPI, and CPI shocks are found to be the major contributors. As such, this exercise displays the importance of examining pass-through relationships more broadly within a system rather than through a single equation.

Beyond this, the results in the paper have a number of implications for monetary policy in the industrialized countries. One is that although external factors have contributed to the disinflation of the $1990 \mathrm{~s}$, their contribution mostly has been modest. Thus much of the decline in inflation during this decade has come from other, presumably more permanent factors, indicating that central banks may have been successful in reducing inflation expectations. Another implication is that fluctuations in exchange rates and import prices will have modest effects on domestic inflation in the industrialized world unless domestic policy mistakes are made. Therefore, even in a more integrated world economy, domestic policies still have a significant role in controlling domestic consumer inflation. 


\section{NOTES}

I would like to thank Palle Andersen, Jose Campa, Mark Gertler, Linda Goldberg, Evan Koenig, Ken Kuttner, Deborah Lindner, Rob Rich, Bill Wascher, Kei-Mu Yi, and two anonymous referees as well as participants of the New York Fed Domestic Department and International Department brown bag seminars, the Federal Reserve System Macroeconomics committee meeting, the New York Area Macroeconomics Workshop, and the 2000 North American Winter Meeting of the Econometric Society for their comments and Rema Hanna for excellent research assistance. I remain responsible for all remaining errors and omissions. Much of the original work on this paper was done while I was visiting economist at the Bank for International Settlements, whose hospitality is greatly appreciated. Please address correspondence to Jonathan McCarthy, Research Department, Federal Reserve Bank of New York, 33 Liberty Street, New York, NY 10045, e-mail: Jonathan.McCarthy@ny.frb.org. The opinions expressed in this paper are mine and do not reflect official views of the Bank for International Settlements, the Federal Reserve Bank of New York, nor the Federal Reserve System.

1. One example articulating the view that special factors were a major contributor to declining inflation in the US during the late 1990s is a speech by then-Federal Reserve Governor Laurence H. Meyer before the Boston Economic Club on June 6, 2000 (“The New Economy Meets Demand," http: / / www. bog.frb.fed.us/boarddocs/speeches /2000/20000606.htm).

2. For example, then-Federal Reserve Governor Meyer in 1999 said, "Finally, international developments clearly are helping to restrain U.S. inflation. No doubt the appreciation of the dollar from the spring of 1995 through mid-1998 has played a powerful role." "Start with a Paradigm, End with a Story: The Value of Model-Based Forecasting and Policy Analysis," speech before the Stern School of Business, New York, November 30, 1999. http://www.bog.frb.fed.us/boarddocs/speeches / 1999/ 19991130. htm.)

In the UK, the Bank of England's May 2000 Inflation Report stated, “...manufacturers' output price inflation remains subdued, partly reflecting intense competition from imports. The sterling prices of imported manufactures have continued to decline, reflecting the appreciation of the exchange rate over the past year." (page 33.)

3. For example, in the Bank of England's Inflation Report, exchange rates and import prices have been among the major considerations for the inflation forecasts underlying the deliberations of the Monetary Policy Committee.

4. See the May 2000 and June 2003 issues of the ECB Monthly Bulletin.

5. In addition, much has been written concerning the related issue of the response of exporters' prices to exchange rate fluctuations. One such paper is Klitgaard [1999].

6. Theoretical antecedents of this model and Clark's [1999] include the production chain model of Blanchard [1983] and the limited participation model of Christiano, Eichenbaum, and Evans [1997].

7. In contrast, Yang [1997] presents a model where import share in an industry is negatively related to exchange rate pass-through. The empirical results, however, indicate a statistically insignificant relationship across US industries.

8. A theoretical argument for this relationship is made in Devereux and Engel [2001].

9. For a short discussion of exchange rate persistence and pass-through, see Branson [1989, 333].

10. As discussed in the introduction, the chain structure of the model is similar to that of Blanchard [1983], Christiano, Eichenbaum, and Evans [1997], and Clark [1999].

11. Even though the data have both cross-sectional and time-series aspects, the model will be estimated for each country separately because differing institutions in each country are likely to lead to different responses in each country (hence the $i$ subscript for each coefficient in the equations).

12. Casual observation suggests that the effect of oil prices on domestic inflation is more symmetric than their effect on GDP. Therefore, I will use the simpler oil price inflation rather than the net oil price increase variable of Hamilton [1996].

13. Empirical research on exchange rates, at least since Meese and Rogoff [1983], suggests that most short-term fluctuations cannot be explained by macroeconomic fundamentals; see, for example, the survey by Taylor [1995]. This simple model thus should be sufficient to identify exchange rate shocks. In particular, we are assuming in this model that money demand and supply shocks do not affect the exchange rate contemporaneously despite theory that would suggest that they should. Nonetheless, we have estimated some alternative versions of the model that allow for money demand and supply 
shocks to affect the exchange rate (and other variables) contemporaneously. The results from these alternatives are substantively the same as those presented in this paper (details are available from the author). Also of note is that Hahn [2003] estimated a model similar to this for the Euro area. She examined several identification schemes that allowed monetary policy variables to affect different variables contemporaneously. These had minimal effects on her estimates of pass-through.

14. For discussion of the effect of monetary policy on estimates of pass-through, see Pigott, Rutledge, and Willett [1985] and Parsley and Popper [1998].

15. See Blanchard and Quah [1989].

16. The German analysis uses all-German data where possible; using only West German data has little effect on the results.

17. In the interest of brevity, details about the data are omitted from this paper. For those interested, an appendix available from the author provides further information about the data.

Although a monthly frequency would be desirable in examining these issues, key variables in some countries are available only quarterly. For example, a lengthy import price series for the United States is available only quarterly.

18. Because of data availability, the estimation period is 1981:2-1998:4 for Belgium and 1978:1-1998:4 for the Netherlands.

19. Using the general PPI irrespective of whether imports were included had little substantive effect on the results outside of the correlation between import share and pass-through to the PPI.

20. See Stewart and Reed [1999] for details in the construction of this series.

21. Alternative methods of computing the output gap that take into account the fact that GDP is difference stationary rather than trend stationary-for example, using the Hodrick-Prescott filter or the permanent component of Beveridge-Nelson decomposition to compute trend GDP-make little difference on the substantive results.

22. For evidence on this in the US, see Bernanke and Blinder [1992].

23. By estimating the model in this way, I am ignoring possible cointegration among the variables. Cointegration tests indicate several possible cointegrating vectors; however, the speed of convergence appears to be slow (similar to that toward PPP; see Rogoff [1996] and Higgins and Zakrajšek [1999]). Given the short horizons studied in this paper, using this simpler model should have little effect on the results.

24. Although the model is estimated in first differences, it is then transformed into levels so that cumulative price level responses are examined.

25. The error bands are estimated using the Bayesian Monte Carlo method employed by RATS with 1000 draws.

26. See Kreinin [1977], Woo [1984], Hooper and Mann [1989], and Goldberg and Knetter [1997].

27. The data to compute these ratios come from OECD National Accounts, Part I.

28. This is the longest period where there are complete data for each of the countries. Using a particular date or subperiod over this interval does not affect the ranking.

29. 1975 was chosen as the year before the estimation period. Choosing a different year or average over the estimation period has minimal effects on the results since the ranking changes only for the two smallest economies in the sample (Sweden and Switzerland).

30. Because the exchange rate shock is standardized to be one percent in all of the countries, so is the initial impulse response of the exchange rate to its own shock. Accordingly, the response of the exchange rate to its own shock at the 8-quarter horizon provides a measure of the persistence of exchange rate fluctuations across the countries. Using the 4-quarter horizon has little substantive effect on the results.

31. The complete variance decomposition of import prices as well as the PPI and the CPI are available from the author.

32. Historical decompositions also were done for the same period for import prices and the PPI, and are available from the author or from the working paper version of this paper [McCarthy, 2000].

33. Because the table displays annualized percentage changes rather than the log differences in which the model was estimated, the contributions do not add up exactly to the projection error.

34. Of course, the Asian crisis probably was one factor behind the oil price decline.

35. See Pigott, Rutledge, and Willett [1985], Parsley and Popper [1998], and Gagnon and Ihrig [2004] concerning the question of central bank reactions to exchange rate fluctuations and estimating passthrough.

Some countries, most prominently Canada and New Zealand, began to use a monetary conditions 
index that includes the exchange rate to guide monetary policy during this period. The countries in this sample did not formally incorporate such an index in their monetary policy deliberations, but they may have informally incorporated exchange rates and import prices into their deliberations.

36. Details are available from the author or from the working paper version of this paper [McCarthy, 2000].

\section{REFERENCES}

Bernanke, B. and Blinder, A. S. The Federal Funds Rate and the Transmission of Monetary Policy. American Economic Review, September 1992, 901-22.

Blanchard, O. J. Price Asynchronization and Price Level Inertia, in Inflation, Debt, and Indexation, edited by R. Dornbusch and M. H. Simsonen. Cambridge, MA: MIT Press, 1983, 3-24.

Blanchard, O. J. and Quah, D. The Dynamic Effects of Aggregate Demand and Supply Disturbances. American Economic Review, September 1989, 655-73.

Branson, W. H. Comment on Hooper and Mann. Brookings Papers on Economic Activity, 1989:1, 33033.

Campa, J. M., and Goldberg, L. S. Exchange Rate Pass-Through into Import Prices. Review of Economics and Statistics, November 2005, 679-90.

Choudhri, E. U., Faruqee, H., and Hakura, D. S. Explaining the Exchange Rate Pass-Through in Different Prices. Journal of International Economics, March 2005, 349-74.

Christiano, L. J., Eichenbaum, M. and Evans, C. L. The Effects of Monetary Policy Shocks: Evidence from the Flow of Funds. Review of Economics and Statistics, February 1996, 16-34.

. Sticky Prices and Limited Participation Models of Money: A Comparison. European Economic Review, June 1997, 1201-49.

Clark, T. E. The Responses of Prices at Different Stages of Production to Monetary Policy Shocks. Review of Economics and Statistics, August 1999, 420-33.

Dellmo, H. Relationships between Swedish Producer Prices and Import Prices and the CPI. Working Paper Number 29, Sveriges Riksbank, 1996.

Devereux, M. B., and Engel, C. Endogenous Currency of Price Setting in a Dynamic Open Economy Model. Working Paper Number 8559, National Bureau of Economic Research, 2001.

Dornbusch, R. Exchange Rates and Prices. American Economic Review, March 1987, 93-106.

Engel, C. and Rogers, J. H. Regional Patterns in the Law of One Price: The Roles of Geography versus Currencies, in The Regionalization of the World Economy, edited by J. A. Frankel. Chicago and London: University of Chicago Press for the NBER, 1998, 153-83.

Feinberg, R. M. The Interaction of Foreign Exchange and Market Power Effects on German Domestic Prices. Journal of Industrial Economics, September 1986, 61-70. . The Effects of Foreign Exchange Movements on U.S. Domestic Prices. Review of Economics and Statistics, August 1989, 505-11.

Gagnon, J. E., and Ihrig, J. Monetary Policy and Exchange Rate Pass-Through. International Journal of Finance and Economics, October 2004, 315-38.

Goldberg, P. K. and Knetter, M. M. Goods Prices and Exchange Rates: What Have We Learned? Journal of Economic Literature, September 1997, 1243-72.

Gordon, R. J. Foundations of the Goldilocks Economy: Supply Shocks and the Time-Varying NAIRU. Brookings Papers on Economic Activity, 1998:2, 297-333.

Hahn, E. Pass-Through of External Shocks to Euro Area Inflation. Working Paper Number 243, European Central Bank, 2003.

Hamilton, J. D. This is What Happened to the Oil Price-Macroeconomy Relationship. Journal of Monetary Economics, October 1996, 215-20.

Higgins, M. and Zakrajšek, E. Purchasing Power Parity: Three Stakes Through the Heart of the Unit Root Null. Staff Report Number 80, Federal Reserve Bank of New York, 1999.

Hooper, P. and Mann, C. L. Exchange Rate Pass-Through in the 1980s: The Case of U.S. Imports of Manufactures. Brookings Papers on Economic Activity, 1989:1, 297-337.

Klitgaard, T. Exchange Rates and Profit Margins: The Case of Japanese Exporters. Federal Reserve Bank of New York Economic Policy Review, April 1999, 41-54.

Knetter, M. M. International Comparisons of Pricing-to-Market Behavior. American Economic Review, 
June 1993, 473-86.

Koenig, E. F. What's New About the New Economy? Some Lessons from the Current Expansion. Southwest Economy, Federal Reserve Bank of Dallas, July/August 1998, 7-11.

Kreinin, M. E. The Effect of Exchange Rate Changes on Prices and Volume of Foreign Trade. International Monetary Fund Staff Papers, July 1977, 297-329.

Krugman, P. R. Pricing to Market When the Exchange Rate Changes, in Real-Financial Linkages Among Open Economies, edited by S. W. Arndt and J. D. Richardson. Cambridge, MA and London: MIT Press, 1987, 49-70.

Mann, C. L. Prices, Profits Margins, and Exchange Rates. Federal Reserve Bulletin, June 1986, 366-79.

Marston, R. C. Pricing to Market in Japanese Manufacturing. Journal of International Economics, November 1990, 217-36.

McCarthy, J. Pass-Through of Exchange Rates and Import Prices to Domestic Inflation in Some Industrialized Economies. Staff Report Number 111, Federal Reserve Bank of New York, 2000. Also available as Working Paper Number 79, Bank for International Settlements, 1999.

Meese, R. A. and Rogoff, K. Empirical Exchange Rate Models of the Seventies: Do They Fit Out of Sample? Journal of International Economics, February 1983, 3-24.

Parsley, D. C. and Popper, H. A. Exchange Rates, Domestic Prices, and Central Bank Actions: Recent U.S. Experience. Southern Economic Journal, April 1998, 957-72.

Pigott, C., Rutledge, J. and Willett, T. D. Estimating the Inflationary Effects of Exchange Rate Changes, in Exchange Rates, Trade, and the U.S. Economy, edited by S. W. Arndt, R. J. Sweeney, and T. D. Willett. Cambridge, MA: Ballinger, 1985, 245-65.

Rich, R. W. and Rissmiller, D. Understanding the Recent Behavior of U.S. Inflation. Federal Reserve Bank of New York Current Issues in Economics and Finance, July 2000.

Rogoff, K. The Purchasing Power Parity Puzzle. Journal of Economic Literature, June 1996, 647-68.

Stewart, K. J. and Reed, S. B. Consumer Price Index Research Series Using Current Methods, 19781998. Monthly Labor Review, June 1999, 29-38.

Stock, J. H. Comment on Gordon. Brookings Papers on Economic Activity, 1998:2, 334-41.

Taylor, J. B. Low Inflation, Pass-Through, and the Pricing Power of Firms. European Economic Review, June 2000, 1389-1408.

Taylor, M. P. The Economics of Exchange Rates, Journal of Economic Literature, March 1995, 13-47.

Wei, S.-J., and Parsley, D. C. Purchasing Power Disparity During the Floating Rate Period: Exchange Rate Volatility, Trade Barriers, and Other Culprits. Working Paper Number 5032, National Bureau of Economic Research, 1995.

Woo, W. T. Exchange Rates and the Prices of Nonfood, Nonfuel Products. Brookings Papers on Economic Activity, 1984:2, 511-30.

Yang, J. Exchange Rate Pass-Through in U.S. Manufacturing Industries. Review of Economics and Statistics, February 1997, 95-104. 